\title{
THERMOCOUPLES AND CABLES FOR NUCLEAR REACTORS
}

\author{
by \\ J. M. Stone \\ Englneering Research Laboratory \\ Engineering Department \\ wilmington, Delaware \\ October 1953
}

Photostat Price $3 \frac{6.30}{3.00}$

Mierefilm Price $\$$

Availiable from the

Office of Technical Services

Department of Commerce

Woshington 25, D. C.

$$
\text { . }
$$

\section{LEGAL NOTICE}

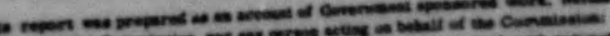

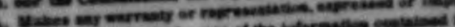

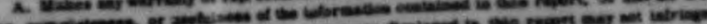

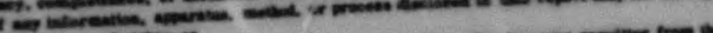

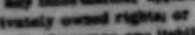

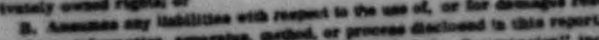

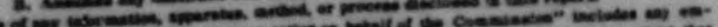

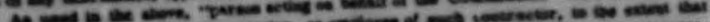

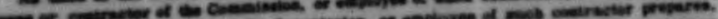

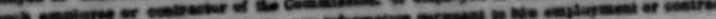

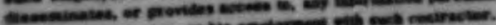

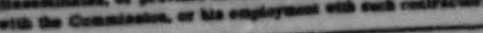

Declassified with deletions Merch 1, 1960.

E. I. du Pont de Nemours \& Co. Explosives Department - Atom1c Energy D1vision Technical Division - Savannah River Laboratory

Contract AT(07-2)-1 with the Un1ted States Atomic Energy Comm1ssion 


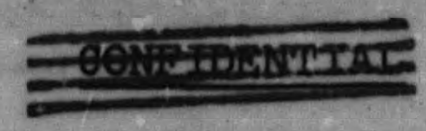

DP -50

Page 5

INSTRUMRNTATION

\section{ABSTRACT}

The development, design, specification, and manufacture of spec1al-purpose thermocouples sheathed in stainless steel for use in nuclear reactors are described, In connection with this work, a three element cable for transmitting the signal from neutron-fiux measuring devices was developed. 


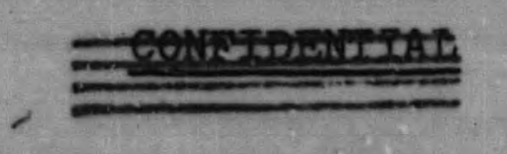

$\mathrm{DP}-50$

Page 6

TABLE OF CCNTENTS

SUMMARY

Page

Problem Inder Invest1gat1on .............

Important Results...................

Recommendation ............... 8

DISCUSSION ..................... 9

Reason for Invest1gation ............ 9

OrIgInal Development Work ........... 9

Type A Thermocouple .............. 12

Insulated Wire : . : . : . : : : 13

Fabrteation Procedurs ........... 13

Inspection Experience :. : . : . : . 14

Inspection Procedure ............. 16

Corrosion Res1stance :.......... 17

Effect of Bending on Thermocouple Accuracy : I8

Effect of Absorbed Hydrogen on Calibration: : 18

Shock Tests ........................ 18

Exposure to Neutron Flux .......... 19

Type B Thermocouple.............. 19

Fabrication Procedure :. :. . . . . . 20

Inspection Experience :. . . . : . : . 21

Inspection Procedure . : . : : : : : : 21

Type C Thermocouple.............. 21

Fabrication and Inspection Procedure : . . . 22

Fabrication Experience........... 23

Type D Thermocouple ............. 23

Fabrication Procedure :. : . . . . : 24

Inspection .............. 25

Bend Tests .................. 25

Type E Thiermocouple ........... 25

Fabrication and Inspection .......... 26

"Trlaxial" Cable ................. 26

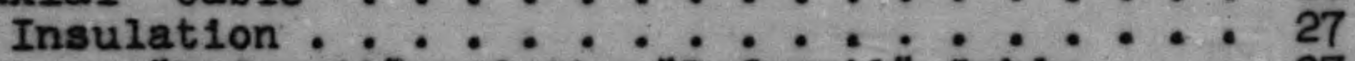

"Refras1i" and the "Refrasil" Cable:. : 27

Asbestos and the Asbestos Cable . . . . 29

Ceramies and the Ceramic Cables.... 30 
TABLE OF CONTENIS (Continued)

\section{FIGURES AND TABLES}

\section{Page}

Figure 1

Figure 2

F1gure 3

P1gure 4

Thermocouple Shock Tester ........ 32

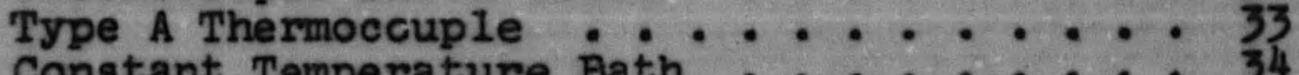

Constant Temperature Bath ........ 34

Multiple Thermocouple Calibration

Switcher ........ 35

F1gure 5 Type B Thermocouple ........... 36

F1gure 6

F1gure 7

P1gure 8

Type C Thermocouple ........... 37

Type D Thermocouple: Bend Test . : : : 38

F1gure 9

"Trlaxiai" Cable ......... 39

Ceram1c-Insulated "Triaxial" Cable: : : 40

Table I Analysis of "Refras11" Sillca Insulation . . 41 


\section{THERMOCOUPLES AND CABLES FOR NUCLEAR REACTORS}

SUMMARY

\section{PROBIEM UNDER INVESTIGATION}

The design of nuclear reactors for the Savannah River Works project called for the use of temperature monltoring is a means to control the reactors and to detect fuel-can fallure. Rapldiy responding thermocouples whlch would operate in a 11quid whlle exposed to neutron flux were required. Th1s study was undertaken to establish the requirements of these thermocouples, to design them, and to locate and Instruct fabricators.

Because of the similarity of the problems involved, this work also Included the development of a cable having three concentric conductors to be used to carry a slgnal from within the reactor to approprlate recording instruments.

\section{IMPORTANT RESULTS}

Five types of 1ron-constantan thermocouples enclosed within metal sheaths have been designed, fabricated, and evaluated. Each thermocouple was prepared for a different severity of exposure. Specifications were written ior use in purchase of the thermocouples.

A three-element cable w1th two tubular conductors concentric about an inner wire was prepared. Resistance between any two elements in this $0.300-1$ nch dlameter cable was 109 ohms minimum for a 35-foot length. The 1isulation used was especially prepared slilca yarn. Spec1fications were written for use in purchasing these units.

Fabricators were located and Instructed In the preparation of the above thermocouples and cable.

Inspection methods to Insure the quality of these thermocouples and the cable were written up and a1d in inftial supervision was given.

\section{RECOMRISNDATION}

The specific thermocouples developed in this study and modifications thereof, should find wide application in other reactors and many processes involved In AEC plants. Small deslgn changes would allow such thermocouples to be prepared for any corrosive environment for which a corrosion-resistant metal capable of being drawn as a tube is avallable.

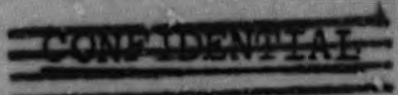




\section{DISCUSSION}

\section{REASON FOR INVESTIGATION}

Th1s st.xdy was authorized in order to develop several types or thermocouples and a concentric three-element cable which were not commerclally avallable. Need for these 1tems was concelved during the original design of the nuclear reactors of the Savannah River Plant.

\section{ORIGINAL DEVELOPMENT WORK}

The original request was for development of a zircontumaluminum thermocouple which would be attached to, and hence could Indicate the temperature of, the fuel cans within an atomic pile. Swelling of fuel cans would cause a decrease in the rate of flow of the cooling medium about the can with a resulting temperature increase. Rapid detection of these fallures was essential.

It was proposed that the thermocouple cons1st of an alum1num wire enclosed within a zircontum tube and insulated from the tube with a material which would withstand neutron bombardment. Lengths of the order of $40 \mathrm{ft}$. and outs1de diameter not In excess of 0.030 inch were desired. Simultaneous formation of the thermocouple hot junction and the sealing of the tubeend were to be accomplished in one welding or brazing operation.

A technlque was developed to braze aluminum to zirconium, but an Investigation revealed: (a) commercial zirconium contains approximately $3 \% \mathrm{Hf}$, an element with a high neutroncapture cross section; (b) acquisition of large quantities of zirconium of closely controlled composition, such as would be required for reproducible temperature-voltage characteristics, would be difficult, if not impractical; and (c) commerciai experlence in handiling large quantities of smali thin-wall zircontum tubing was n1l.

Consequently, the design was changed to a thermocouple consisting of an aluminum tube drawn over an insulated constantan wire. The dimensions were not changed. Such thermocouples were made under EngIneer Ing Research Laboratory (E. R. L.) sponsorship by the Precision Tube Co., Philadelphia, Pa. A method for the formation of the lot junction was developed at the B. R. L. as follows. After threading an insulated wire through the tube, the center wire was allowed to extend bare beyond the end of the tube, which was swaged down upon the wire. 


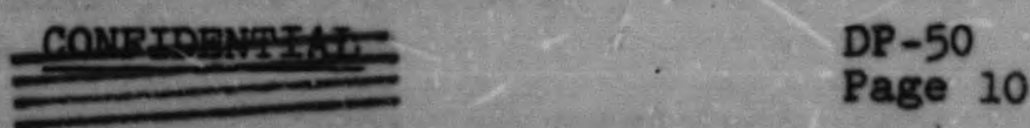

The wire was then wrapped back up around the tube end. SealIng of the tube end and brazing of the two elements at the Junction was then accomplished by dipping the joint into a bath of molten aluminum-s111con eutect1c (13\% S1 in aluminum) held at $11000 \mathrm{~F}$. Any one of many aluminum fluxing compounds could be used to cover the surface of the bath (examples: Aluminum Company of America Pluxes 34 or 53).

These thermocouples consisted of a 0.008 -inch diametar constantan wire covered with a varnish-impregnated. Insulation over wh1ch was drawn a 0.030 -1nch 0 . d. x.0:006-Inch wall $2 S$ aluminum tube. Precision Tube Co. had never arawn such small-size aluminum tubing in lengths greater than $15 \mathrm{ft}$. They prepared $s 1 x$ thermocouples in lengths jlist exceeding 40 feet. Owing to splits in the tubing during the drawing operation, they lost three assemblias for each one they completed.

Varnish impregnation and boron-containing "F1berglas", glass fiber insulation such as were used in these thermocouples were not considered sat1sfactory, but they allowed development of the tube drawing and brazing arts. Organic materlals might decompose under neutron bombardment. Materlals with high neutroncapture cross sections, such as the boron in the "Fiberglas", were not desirable.

An Insulation materlal which showed promise was a leached "P1berglas" yarn, approaching pure s1l1ca in composition, sold under the name of "Refras11" by the H. I. Thompson Co., Los Angeles, Callfornia. Samples revealed "Refrasil" s1lica insulation to have poor tensile strength and abrasion resistance. Considerable effort was expended by three w1re-1nsulating companies to develop a technlque to braid or wrap "Refras11" on a small-diameter wire. Bralding was finally accomplished by soakIng the "Refras11" in a mixture of equal parts by volume of carbon tetrachloride and kerosene before application. Although this wolld have required leaching the insulation with a solvent before enclosure in the tube, it was the only means found which approached pract1cab1l1ty.

It was intended that these thermocouples be joined to fuel cans by brazing. However, reports of tests just completed at Hanford revealed that attempts to braze to the cans resulted in an unusually high rate of can fallure. Th1s information forced the conception of a new design.

Fuel cans in the Savannah River reactors are so arranged that. a rise in temperature of the coolant would reveal the onset of a potentialiy dangenous condition. This was the basis for the next design. 
It was known from experience at Hanford that asbestos is an Insulator which w11l withstand neutron bombardment. Asbestos could not be used on the early thermocouples of this atudy hecause $1 t$ could not be applled in thin enough wall thicichesses to allow a maximum overal1 diameter of 0.030 inch. The proposed position of the thermocouple junction made $1 t$ possible to increase this diameter to $1 / 8$ inch.

There were several methods used commerclally to apply asbestos to a wire, and all of them Involved the use of added organic materials. One did offer hope of modiflcation which would avold such additions. Th1s technique consisted of feltIng the asbestos about the wire with equipment similar to text1le cards. Usually, commerclally applied asbestos contalris 5 - $30 \%$ cotton and 1 s held in place after application w1th an organic binder.

Samples of cotton-free asbestos lap were secured from the Raybestos-Manhe1m Co., Manhe1m, Pa. Th1s asbestos was successfully applied to a $0.032-1$ nch diameter constantan w1re, using distilled water as a binder by the Lewis Engineering Co., Naugatuck, Connect1cut and the General Electric Co., York, Pa. The Precision Tube Co. took this covered wire--now 0.080 inch In diameter-tand drew over it a 0.125 -1nch $0 . d$. $\times 0.020$-1nch wal1 $2 S$ aluminum tube. In this larger size, length was no longer a problem. Welded hot-junctions were successfully formed at E. R. L. using the Inert gas shielded arc method. To insure a sound thermocouple junction and tube seal, the following practices had to be observed: (a) the area near the weld was kept ent1rely free of asbestos (b) the t1p of the aluminum tube was swaged down on the constantan w1re, and (c) welding was accomplished by using $60 \mathrm{c} / \mathrm{sec}$. alternating current of the order of 5 - 10 amps with a cont inuously superimposed highfrequency current; and (d) a copper chlll block was placed around the aluminum tube because of the low melting point $\left(1215^{\circ} \mathrm{F}.\right)$ of the aluminum tube relative to constantan (2355\%).

The large difference in the coefficlents of thermal expansion of aluminum and constantan ( $23.9 \times 10-6^{\circ} \mathrm{ln} . /(1 \mathrm{n}).\left({ }^{\circ} \mathrm{C}\right)$ and $14.9 \times 10^{-6} \mathrm{in.} /(\mathrm{In}).\left({ }^{\circ} \mathrm{C}\right)$, respect 1 velv $)$ made $1 \mathrm{t}$ necessary to consider the possibility that the aluminum tube might puli away from the constantan wire during heating. Likelihood of this was Increased because of a brittle CuAla phase which might form between the copper in the constantan and the aluminum during welding.

A shock testing unit, shown schematically in F1gure 1 was designed to invest1gate this possib1lity. Forty-e1ght thermocouples were placed in the tank. They were exposed 


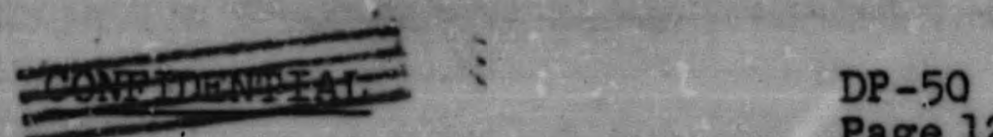

Page 12

alternately to $5 \mathrm{~min}$. of cold water followed by $5 \mathrm{~min}$. of steam at $1 \mathrm{~atm}$. pressure. Voltage output of the themnocouples was noted on a Brown recorder to which the output of each thermocouple was successively switched.

All of the thermocouples falled within three days. Upon opening of the tank, It was evident that falled junctions were not the sole cause of the difficulty. Vibration resulting from the flow of water and stean had caused the aluminum tubes to wear against one another unt1l the walls had perforated; then the asbestos Insulation had become saturated with water. Sectioning of all of the welded functions showed that separation had occurred in only three units; all. of these had given a faulty temperature Indlcation as scon as the test began. These welds had not been properly made and had not falled because of the test. The susceptibli1ty of the thermocouples to wear was revealed.

A new thermocouple with the aluminum tube replaced with one of Type 304 stainless steal was prepared. Asbestos-1nsulated constantan w1re was again used.

While these thermocounles were on order, the neutron flux concentration at their planned location was reappraised. The new estimate of the neutron flux concentration was such a low value that organics and elements having high neutron-capture cross section did not need to be avolded. An order was placed w1th the Posen and KlIne Tube Co., Norrlstown, Pa. to draw Type 304 stainless steel sheaths over conventional iron-constantan thermocouple wire pairs insulated with varnish-1moregnated "Fiberglas." Out of this work came the Type A thermocouple, which is described in detail below.

The Inclusion of two wires that are commoniy used for thermocouples was of a distinct advantage because 1 t eliminated the necessity of securing large quantities of stainless steel tubIng of reproducible temperature-voltage characteristics. It also eliminated possible formation of natural thermocouples between the reactor shleld and the thermocouple sheath, which could considerably alter the true signal from the thermocouple.

Forty-e1ght stainless-sheathed thermocouples (16 singlewire and 32 double-wire) were exposed in the shock testing unit for over 7,000 cycles. Three w1th bad welds operated Inaccurately immediately and the remainder survived the entire test.

\section{TYPE A THERMOCOUPLE}

This thermocouple with the iron-constantan wires insulated with asbestos in a stainless steel sheath was labeled "Type A." 
An order for the total Savannah River Plant requirements was placed with the Posen and Kline Tube Co. It is 1ilustrated in plgure 2.

Insulated W1re The thermocouple wires were of 1ron and constantan. Each bare wire was 0.032 inch in diameter. Individual wires were wrapped in varnish-1mpregnated "F1berglas." The Iron and constantan wires were palred so that the temperature Indicated by the e.m.f. of any one pair did not vary from that of any cther pair by more than $0.44^{\circ} \mathrm{C}$ when the hot junction was held at $50^{\circ} \mathrm{C}$ and the cold Junction at $30^{\circ} \mathrm{C}$. When properly matched, the palred w1res were covered w1th a varnish-1mpregnated "Fiberglas" braid. The varnish impregnation was not allowed to penetrate the, Insulation to the wire as this would have necessitated an especially careful cleaning of the wire to assure a sound hot junction weld. Wire meeting these specifications was ordered from the Brown Instrument Co. for the flrst order.

\section{Fabrication Procedure}

a. The Insulation is stripped for $3-4$ inches from the end of an approprlate length of 1ron-constantan palred wires.

b. This length of palred wires is threaded through an oversize (approximately 3/16-1nch o.d.) 0.020-1nch wall Type 304 stainless steel cover. A length of plano wire can be used to draw the wire in the tube. Welded tubing is used here in preference to seamless because of its lower price (20\% lower).

c. With the paired wires drawn through the tube, the stripped ends of the wires are cut back so that only $3 / 8$ Inch is uninsulated.

d. The wires are drawn back Into the tube unt1l the stripped ends are $3-4$ inches from the end of the tube.

e. A swaging machine 1s used for "pointing" this end of the tube so that $1 t$ w11l eas $11 y$ slip into a $0.125-$ Inch dlameter tube-drawing die.

f. The tube $1 \mathrm{~s}$ drawn down to a $0.125 \pm 0.002$ Inch o.d. on a standard small-tube bull block.

g. Arter removing from the bull block, a small wire probe is inserted into the swaged end to determine preclsely the position of the ends of the wires.. 
h. Having established thase positions, the swaged end of the tube is trimaned off with a smail cut-off wheel so that the ends of the wires and the end of the tube are $\mathrm{flush}$.

1. As shown In Figure 2, the end of the tube is swaged again to bring the tube down on the uninsulated wire. Th1s causes the end of the tube to approach the welding characteristic of the end of a rod. Moreover, should the weld "ball up" slightly, 1ts diameter w1.11 st111 be less than the $0.125-1$ inch diameter of the tube and 1t w111 pass through any opening that the tube will clear.

1. Th1s second swaging operation causes the tube to grow slightly so that its end is not now flush with the wire ends. Because of this, the tube $1 \mathrm{~s}$ again trimmed with the cut-off wheel until it is flush with the wire.

k. The thermocouple junction is formed by welding, using the Inert-gas shlelded arc method w1th a current of about 15 amps., stra1ght polarity (electrode negat1ve) and an argon gas shleld. A section of a typlcal weld is shown in Figure 2. The thermocouple is now ready for Inspection. Care must be taken duririg fabrication to see that the interior of the tube is clear and free from lubricants. Th1s is especially true for that portion of the tube near the weld, because such contamination can be the cause of a leaking weld.

Thermocouples as long as $78 \mathrm{ft}$. were prepared according to this design. Th1s was longer than was contemplated for plant use, where the maximum length was approximaiely. 35 feet.

Inspection Experfence Four hundred and ten Type A thermocouplss ordered for testing and experimental use were inspected at the E. R. L. Each thermocouple was subjected to s1x tests as follows:

a. Speed of response. The length of time required for the thermocouple to indicate $60 \%$ of the total temperature differential when $1 t$ was rapldiy changed from $0^{\circ} \mathrm{C}$ to $100^{\circ} \mathrm{C}$ was established with the ald of 2 Brush recorder.

In this test, the time varled from 0.27 to $1.70 \mathrm{sec}$. S1x thermocouples w1th responses of from 1.37 to 1.70 
seconds were sectloned and found to meet fully the specification that the length of uninsulated wire at the hot-Junction end could be no longer than $7 / 16$ inch. The mean response was $0.71 \mathrm{sec}$; the standard deviation was $0.22 \mathrm{sec}$, ; and the threesigma limit (wh1ch includes approximately $99.7 \%$ of the cases) was 0.65 sec., a rather large spread.

b. Indicated temperature accuracy was determined. Voltage output with the cold function at $00^{\circ} \mathrm{C}$ and the hot junction at $100^{\circ} \mathrm{C}$ was measured with a semiprec1sion potent1ometer. Th1s output voltage was compared w1th a Brown Instrument Co. standard 1ronconstantan curve to arrive at a corresponding temperature value. Deviation of this temperature from the differential between callbrated thermometers in the hrit and cold bath was recorded.

On the temperature calibration test, only two thermocouples were refected: one reading $15^{\circ} \mathrm{C}$ low and the other $60^{\circ} \mathrm{C}$ low. According to the speciflcation on which the w1re for the thermccouples was purchased, the range of accuracy could vary $2.2^{\circ} \mathrm{C}$ over a $100^{\circ} \mathrm{C}$ range. The range for the accepted thermocouples tested was $1.4^{\circ} \mathrm{C}$. The mean value of these thermocouples was $0.40^{\circ} \mathrm{C}$ under the Brown Instrument Co. standard curve; the standard devlation was $0.23^{\circ} \mathrm{C}$; and the three-s1gma $11 \mathrm{~m} 1 \mathrm{t}$ was $0.68^{\circ} \mathrm{C}$.

c. The dlameter of each stainless steel sheath was. measured.

Every thermocouple sheath was found to meet the specifications of $0.125 \neq 0.002$ inch in diameter.

d. Each thermocouple weld bead was passed through a 0.125 -inch diameter gage to show that 1 was not oversize.

Bvery weld bead passed through 0.125 -1nch gage as required.

e. Res1stance between the Iron wire and the constantan wire leads of each thermocouple was measured w1th a Simpson test meter.

Res1stance of the thermocouples varled from 10 to 23 ohms. No open c1rcults were detected. Varlation was due to the $11 \mathrm{~m} 1$ ted accuracy of the measuring 
Instrument used and to the different thermocouple lengths. The measurement taken was that of the Iron and constantan wires in serles.

f. A leak test of the sheaths was run. Each tube was filled with hellum to a pressure of $500 \mathrm{lb} . / \mathrm{sq} .1 \mathrm{n}$. and the welded $t 1 p$ and $6 \mathrm{ft}$. of tubing at the weld tip end were checked with a hellum leak detector.

Leak testing revealed 82 faulty thermocouples. Of these, 52 had leaky welds and 30 had split tubes. Seventy-elght were returned to the fabricator. for replacement and the remainder were held for sectioning. According to the fabricator, 5\% split tubes is normal. Hence, the $7.1 \%$ was not greatly out of 1 ine. Twelve and three-tenths per cent of the tubes wh1ch exh1b1ted leaky welds were not representative of typical production. The order was delivered in two parts of 265 thermosouples and 145 thermocouples, the latter part arriving about six weeks after the f1rst delivery. Of the 145 , only two (1.3\%) had leaky welds and elght $(5.1 \%)$ had spl1t tubes. Lack of experience on the part of the welder was no doubt responsible for the large number of leaky welds in the first part of the order. Nany of the splits occurred beyond the f1rst $6 \mathrm{ft}$. of the thermocouple, but, since they made 1 t Impossible to bu1ld up hellum pressure in the weld region, these thermocouples were also rejected.

Inspection Procedure The following procedure was recommended for Inspection of all Type a thermocouples.

a. Each thermocouple is checked for the accuracy of 1ts temperature-voltage relationship. The hot bath may be made according to Figure 3 . Th1s bath contains bolling dist1lled water at a constant level. No more heat should be applied than is necessary to malntain bolling. Bolling chips should be used. A thermometer certifled to be correct within $0.1^{\circ} \mathrm{C}$ is used to measure the water temperature. The two wires extending from the opposite end of the thermocouple sheath are connected to a palr of the terminals of the multiple thermocouple calibration switches, shown in F1gure 4.

Th1s sw1tcher apparatus provides a means of calibratIng these thermocouples on a production-11ne basis. Ten thermocouples can be inserted in bo111ng water 


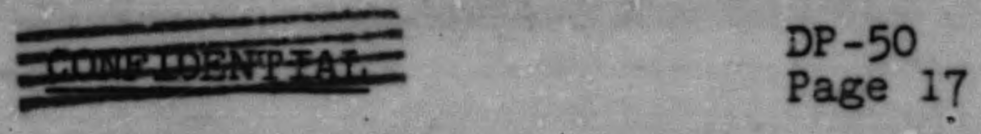

and connected to cne side of the ewitcher. While one operator is rotating Sw1tch No. 1, recording the temperature from the indicator, and comparing this temperature to that indicated on the thermometer, another operator can be inserting a second set of thermocouples in a second bath and connecting them to the other side of the switcher.

W1re for the Type A thermocouples was purchased according to a speciflcation stating that the e.m.f.'s of the wire palrs purchased cannot differ from each other by more than $0.44^{\circ} \mathrm{C}$ when the hot junctions are at $50^{\circ} \mathrm{C}$ and the cold junctions are at $30^{\circ} \mathrm{C}$. Since the cal1bration test takes place at $100^{\circ} \mathrm{C}$ and $0^{\circ} \mathrm{C}$, maximum variation of $5 \times 0.44^{\circ} \mathrm{C}$, or $2.20^{\circ} \mathrm{C}$ is allowed. Experience with the NYX thermocouples showed that $99.7 \%$ of these had a maximum varlation from one another of only $1.35^{\circ} \mathrm{C}$.

b. A measurement of the diameter of each thermocouple ahould be made at some random point along the length In two positions 900 apart to insure roundness. The diameter must be $0.125 \pm 0.002$ in.

c. Weld-bead diameters should be checked to detect any which might be oversize. Each bead should pass through a $0.127-1$ ch djameter hole. A standard tube or wire-drawing die is recommended as a test gage.

d. The resistance between the iron wire and the constantan wire should be measured. Resistance should not exceed 25 ohms. Th1s is for thermocouples having maximum length of $35 \mathrm{ft}$., which includes all Type A thermocouples ordered.

e. Each thermocouple should be filled with hellum to $5001 \mathrm{~b} . / \mathrm{sq} .1 \mathrm{n}$. and searched w1th the probe of a hellum leak tester (Consolldated Englneering Corp.). Tubes leaking at the weld or within $6 \mathrm{ft}$. of the weld should be rejected. If rewelding corrects the the leak, the thermocouple can then be accepted.

Corros1on Res1stance Type A thermocouples were to be exposed to extremely high purity water. Stainless steel sheathing was chosen because of its good corrosion resistarice. However, the weld bead is not stainless steel but a mixture of stainless steel (18\% Cr -.8\% N1 - balance Fe), 1ron, and constantan (55\% N1, $45 \% \mathrm{Cu}$ ). Ten thermocouples with the standard weld bead 
(F1gure 2) and ten whose weld beads had been enriched w1th "N1chrome" $(80 \% \mathrm{N1}, 20 \% \mathrm{Cr})$ w1re were exposed to h1gh-pur1ty water at $600 \mathrm{C}$. for 10 weeks. Careful microscoplc examination revealed no attack on elther the standard or the enriched bead.

Effect of Bending on Thermocouple Accuracy The sharpest bend to be made in a Type A thermocouple was a 3 -inch radius $180^{\circ}$ bend. Four such thernocouples were siven three turns around a $1-1 / 2-1$ inch radius pipe. The ir callbrations in bolling water before and after bending were compared. No change was found.

Effect of Absorbed Hydrogen on Callbration It was proposed that the vater environment of the thermocouples might be very slightly Ionized as a result of pile reactions. A test was run deliberately exaggerating the hydrogen influence to determine the effect of possible hydrogen absorption. A $0.1 \mathrm{~N}$ solution of nitric acid was held in a constant temperature bath at approximate $1 y 50^{\circ} \mathrm{C}$. The ends of a Type 304 stainless steel rod and a 10-Inch long Type A thermocouple were heid in the solution and connected to a $6-\mathrm{V}$ battery for $99 \mathrm{hr}$. w1th the thermocouple as the cathode. Gas evolution from the thermocouple surface was vigorous. Immediately adfacent to the thermocouple, but not touching it was a second thermocouple and a laboratory thermometer. The potantlal developed by the two thermocouples was measured before and after exposure to the hydrogen evolved by electrolysis. The thermocouple which served as the cathode read $0.13 \mathrm{mv}$. higher than the standard Brown Instrument Co. curve before the test and $0.006 \mathrm{mv}$. higher than the curve after the test. The second thermocouple (not in the electrical c1rcult) read $0.010 \mathrm{mv}$. lower than the curve before the test and $0.009 \mathrm{mv}$. lower than the curve after the test.

The amount of hydrogen developed at or near the surface of each thermocouple was far in excess of that wh1ch is est1mated for the service conditions and yet the varlation of the two thermocouples was within the accuracy of the measurement.

Shock Tests The shock testing unlt described prevlously (FIgure 1) was used to test the Type A thermocouple. P1fteen of these and 17 differing only in that the stainless steel sheath wall thickness was 0.010 inch instead of the standard 0.020 Inch were run for over 7,000 steam-cold-water cycles (over 14,000 temperature reversals). Two of the thin-wail thermocouples falled, both within the first 


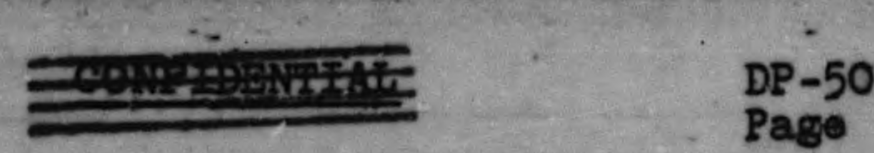

hour. Bach had given a h1gh resistance measurement (approximately 400 ohms) between the Iron w1re and the conatantian vire prion to installation, Indicating incomplete welding. The remaining therrocouples were still performIng satisfactorily at the end of the test.

Exposure to Neutron Flux Tests in which the Type A thermocouples were exposed to flux concentrations equivalent to or exceeding service conditions were mun. Six such thermooouples were inserted in the CP-3 heavy-water moderated reactor at the Argonne Nat1onal Laboratory and held there for 20 days.

These thermocouples were fabricated with no welded junction so that the Iron wire and the constantan wire were eleotrically separate. Thus, a simple resistance measurement between the two wires would have shown insulation fallure if it had occurred. No such ohange was detected.

The tube, however, was closed by welding at the hot-junction end. The open end was connected with a manometer system in order to measure any gas generated within the tube owing to decomposition of the varnish on the Insulation. No change in the manometer reading was detected after 20 days. The system was accurate to $0.1 \mathrm{cc}$.

\section{TYPE B THERMOCOUPLE}

According to the reactor des1gn, the reference Junction for the Type A thermocouples would be placed in a position where 1ts temperature would follow the temperature of the coolant as it enters the ractor after leaving the heat exchangers. Thus, if the Incoming water vavies in tamperature, the e.m.f. reading of the Type A thermocouple would not be infiuenced. Type A thermocouvies would then read only the change in coolant temperature 
that takes place 1: tie reictor. The reierence thermocouple has been labeled Type B.

Actually, 1t was very similar to Type A, differing only in the fornation of the thermocouple junction. As can be seen from F1gure 2, the Type A thermocouple had the two wires welded to the stainless sheath. Th1s prov1ded a very rap1d temperature response. Rap1d temperature changes were not to occur at the location of the reference Junction and rap1d response was not a requirement. The essent1al features of the Type B thermocouple can be seen In Figure 5. A "Fiberglas" sleeve was used to Insulate the junction from the stainless sheath. Th1s was necessary to avold an electrical path from the Type A Junction through 1ts stainless sheath, the reactor shell and the Type B sheath to 1 ts junction.

Fabrication Procedure The steps in the fabrication of the Iype $B$ thermocouple are as follows:

a. The Insulated thermocouple wire is threaded through a $3 / 16-1$ nch $0 . d$. $x$ 0.020-1nch wall, Type $30^{4}$ stainless steel tube w1th plano wire. Welded tubing is used. The wire must meet the same specifications as that of the Type A thermocouple.

b. With the wire through the tubing, the 1nsulation 1s stripped from one end for $2-3$ in. The two exposed wires are twisted together and then cut off unt1l only $3 / 8 \mathrm{in}$. or less $1 \mathrm{~s}$ uninsulated. The w1res are welded together with an oxyacetylene torch using no flux. Each weld is inspected visually to see that thorough fusion has taken place.

c. A 1-1n. long "Fiberglas" sleeve is slipped over the exposed thermocouple junction. The sleeve serves to insulate the junction from the stainless sheath. The particular sleeving used successfully was "Ben Hax A.S.T.M. Grade A spec1altreated "F1berglas" tubing, size No. 18" as supplied by, the Bentley-Harris Co., Conshohocken, Pa.

d. The wire 1s drawn back into the tube so that the welded junction is within the stainless tube and 3 - 4 1n. from the end of the tube. Th1s end of the tube 1s then swaged down unt11 $1 \mathrm{t}$. w11l pass through a $1,8-1$. die. 


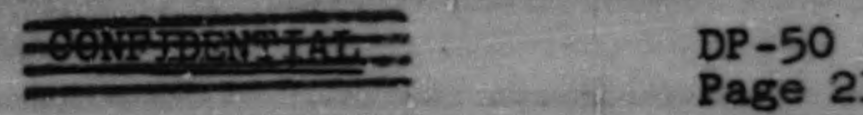

e. A small standard tube bull block 1s used to draw the tube down to $0.125 \pm 0.02-1$. 0 . d.

r. Remove the drawn tube from the bull block and Insert a wire probe Into the swaged end to determine precisely the position of the end of the wire.

g. The swaged end of the tube is trimmed off w1th a small cut-off wheel so that the end of the tube extends $1 / 4 \mathrm{in}$. beyond the welded junction.

h. Th1s end of the tube is swaged again if necessary to decrease the dlameter and make it easier to weld.

1. The end of the tube is sealed by welding by the Inert-gas shlelded are method using a thorlated tungsten electrode, stralght polarity and direct current of about 15 amp. The thermocouple is now ready for inspection.

Irspection Experience Twelve Type B thermocouples were Inspected for NYX at the same time as the 410 Type A thermocouples were tested. The temperature response was, as could be expected, slower than that of the Type A thermocouples, requiring $1.53-1.90$ seconds to follow $60 \%$ of a temperature change of $0^{\circ}-100{ }^{\circ} \mathrm{C}$. No thermocouple varled from the Brown Instrument $\mathrm{Co}$. standard 1ron-constantan curve by more than $0.1^{\circ} \mathrm{C}$. Only one was rejected because of a short circult from the wires to the stainless sheath.

Inspection Procedure A11 Type B thermocouples are Inspected by the same procedure used for the Type $A$ thermocouples. In addition, one measurement of resistance is made to show that the thermocouple junction is insulated from the stainless steel sheath.

\section{TYPE C THERMOCOUPLE}

The third type of thermocouple, referred to as Type c, was designed for use at points within the reactor where the neutron flux concentration was expected to be great enough to decompose the varnish-1mpregnated "Fiberglas" insulation used in the Type A thermocouple, but where the thermocouple would 11 along a neutron-absorblng seal so that 1.ts neutron-capture cross section was not a signif1cant factor. 
A diagram 11lustrating the essential features of the Type $c$ thermocouple is shown in Figure 6 . The basic differences between this and the Type A thermocouple were the wire size and the irsulation. B. \& S. gage No. 24 (0.020-in. diam.) Iron wire and constantan wires were used as more space was required within the 0.085-1n. 1.d. Type 304 stalnless steel sheath to accommodate the asbestos insulation.

Experience at the Hanford Plant had shown that asbestos would withstand exposure to high neutron flux and that organic materials generally would not. Commerically avallable asbestos for use as a wire insulator contains from 5 - $30 \%$ cotton and usually is 1mpregnated with an organic binder to hold $1 t$ in place on the wire. Both cotton and the binder were thought to be objectionable for this application, hence, 1t was necessary to find a means of eliminating them.

Two methods of applying asbestos to wire are used commerclally. One is to mat the asbestos fibers (containing 5\% or more cotton) about a cotton, rayon, nylon, or "Fiberglass" thread and to wrap this matted thread around the wire. The other is to gather cotton-contalning asbestos fibers around the wire by feeding from a modifled textlle card. The fibers are spun tightly against the wire and 1mpregnated w1th an organlc binder to hold them in place. The latter method was chosen as the one which could be most easily changed to meet our requirements.

W1th the cooperation of the Raybestos-Manhe1m Co., Manhelm, Pa., a lot of select long-fiber Canadlan asbestos with no cotton adaltion was secured. The General Blectric wire and cable plant at York, Pa., succeeded In adjusting the 1r cardiris machinery to handle this cotton-free asbestos lap. Organic binder was replaced with dist1lled water. The resulting insulation had much the appearance of a felt.

Fabrication and Inspection Procedure No. 24 gage $(0.020$ In. diam.) 1ron and constantan wires are each covered witb a thickness of 0.007 1nch of asbestos, and the pair is then covered with the same thickness. Asbestos as applied to individual wires and to the pair is wet throughout with dist1lled water. Because th1s water w111 corrode the 1ron wire and lower the electrical resistance of the asbestos, 1t is necessary to remove all except the water of hydration Immediately and all water eventually. 


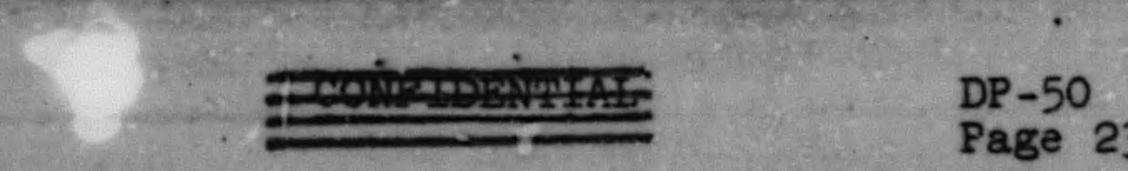

One-thousand-foot lengths of both single wires and wire pairs are heated with infrared lamps as they are spooled from the felting machine. The spools are held In an electrically heated oven at at least $110^{\circ} \mathrm{C}$ for at least two days before the next layer of insulation is applied or unt1l they are paskaged in "VPI" (vaporphase inhibitor) Impregnated paper bags.

The thermocouples are fabricated in essentially the same manner as the Type A thermocouple. After fabrication and before inspection, each thermocouple is heattreated for $3 \mathrm{hr}$. at $1050^{\circ} \mathrm{F}$ to remove the water of hydration from the asbestos. After alr-cooling, the open end of the thermocouple is sealed w1th "Glyptal" enamel.

Thermocouple inspection procedure is the same as for the Type A thermocouples except that the maximum resistance allowed when measuring along the two conductors may be no mors than 50 ohms.

Fabrication Experlence The necessity of the high-temperature heat-treatment was pointed out quite markedly during fabrication. Thermocouples assembled and heattreated w1thin 2 months after the asbestos was applied to the wires were found to be satisfactory. Thermocouples assembled and heat-treated 4 months after insulation of the wire had a very high rejection rate. Th1s was due to pitting of the iron wire, presumably by molsture trapped in and made alkaline by the asbestos. The importance of fabricating and heat-treating the thermocouples as soon as possible after wire insulation cannot be overstressed. Because of th1s problem, many Type C thermocouples were later replaced w1th Type B thermocouples, as described later.

\section{TYPE D THERMOCOUPLE}

The fourth.type of thermocouple was for use within the heart of the reactors. The absorption of neutrons by the thermocouple was of as much concern as was the influence of these neutrons on the thermocouple materials. These Type D thermocouples were to be used w1thin the instrument tubes to provide a temperature profile of the reactor. Type D thermocouples differ from Type C thermocouples malnly in use of $2 S$ aluminum instead of

- stainless steel sheath and in the use of smaller wire size. 
Fabrication Procedure The wire used is 1ron-constantar of B. s. gage No. $30(0.010-1$. diam.), the smallest size of any of the thermocouples so that a minimum of neutron-absorbing materials is present. The insulation is the same high-purity cotton-free asbestos felt used on the Type $C$ thermocouple. Each wire is covered w1th $0.010 \mathrm{in}$. of 1nsulation and the two Insulated wires are covered w1th another 0.010 in. of asbestos.

The sheathing material is $2 S$ aluminum tubing, replacing the stainless tubing $(0.125 \pm 0.002-1 n c$. 0.d. $x 0.020-1 n$. wall) used on Types A, B, C and E. All tube drawing for this assembly was done byithe Precision Tube Co., Philadelphia, Pa. The fabrication procedure, similar to those given previously, is as follows:

a. The asbestos-insulated wire pair is drawn through a 3/16-1n. 0.d. $x$ 0.020-1n. wall 25 aluminum tube w1th a length of plano wire.

b. After the wire is threaded through the tube, the insulation is stripped from one end for a length of $1 / 4$ $3 / 81 \mathrm{n}$.

c. The two wires are spot-welded together, and the weld is examined visually for soundness of the junction.

d. The exposed junction is covered by a spali amount of the same kind of asbestos as is used for the Insulation. The junction should be so covered that when the thermocouple is completed the w1res w1ll be electricaliy insulated from the aluminum sheath. False readings w1ll result if this is not done.

e. The wires are drawn back into the sheath so that the welded Junction $1 \mathrm{~s} 3-4$ in. From the end of and withIn the sheath.

f. This end of the sheath is then swaged down for $2-3$ 1n. unt11 it w111 pass through a $1 / 8-1 n$. die.

g. The drawing operation is performed by reducing the aluminum tube to $0.125 \pm 0.002-1 n$. 0.d. $x 0.020-1 n$. wall on a standard bull block.

h. A small wire probe is inserted into the swaged end to determine the position of the thermocouple junction.

1. The swaged end is cut off so that the junction $1 \mathrm{~s} 3 / 8$ In. Inside the tube. 
J. The end 1s reswaged to bring the diameter down to $0.090 \mathrm{In}$. or less and 1s swaged back no farther than $3 / 8$ in.

k. The end of the tube is welded using the 1nert-gas shlelded arc methol. A tungsten electrode is used with approximately $10 \mathrm{amp}$. of $60 \mathrm{c} / \mathrm{sec}$. alternating current plus a cont inuously superimposed high-frequency $(1-2 \mathrm{Mc} / \mathrm{sec}$.) current.

1. The thermocouple is heat-treated at $1025 \%$ for 3 hr. All comments pertaining to the necessity of heat-treating the Type $C$ thermocouple as soon as possible after insulating the w1re apply here.

m. The thermocouple is ready for inspection.

Inspection Inspection of the Type D thermocouple is 1dent1cal with. that of the Type A thermocouple w1th three except1ons: (a) a continuity check must be made to show that the wire is electrically insulated from the sheath, (b) the resistance between the two wires should not exceed 200 ohms for a length of $50 \mathrm{ft}$. or less, and (c) the thermocouple sheath should be submerged in a tank of water for three-quarters of 1ts length from the seal end for one week. The resistance between elther wire and the sheath must not decrease in this time. Th1s is a leak test wh1ch is performed in addition to the hellum test, wh1ch w1ll not always be effect1ve w1th asbestos-1nsulated thermocouples. The asbestos can, in some cases, act as a gasket to prevent the passage of hellum through the tube.

Bend Test The planned installation of the Type D thermocouple called for a slight (approximately 150) bend near the weld end. The test 1llustrated in Figure 7 was performed to show that even sharp $90^{\circ}$ and $180^{\circ}$ bends do not break the w1res, rupture the sheath, or short-c1rcult the wires to one another or to the sheath. A cont1nulty check showed no short-c1rcults or w1re breaks, and microscoplc examination did not reveal tube rupture.

\section{TYPE E THERMOCOUPLE}

Information avallable on the behavior of organic materials in atomic-reactor environments was quite i1mited. Therefore, when a high-flux density reactor for materlals testing became avallable, several thermocouples made with commercially ava11able wire were exposed. These thermocouples were 1dentical with other stainless-sheathed assemblies previously described, except for the Insulation and that the two wires were not 
Joined in a thermocouple jurction. It was possible to follow any changes in the resistance of the insulation simply by reading the resistance between the two wires or between elther wire and the sheath at the open end of the thermocouple extending from the pile. This technique was previously described for the Type A thermocouple (Page 16).

S1x such thermocouples made w1th Leeds \& Northup Catalog No. 50-4 1nsulated 1ron-constantan w1re were exposed for 50 days In the Materials Testing Reactor at Arco, Idaho. During this $t$ Ime, the resistance between the w1res varled erraticalIy from $55-1,000$ megohms when inserted into the p1le.

Because of the 1ron wire corrosion encountered in the fabrication of the Type $C$ thermocouples, w1re 1dent1cal w1th that used in th1s test was ordered and has since been used for thermocouples in positions previously set aside for Type C.

Fabrication and Inspection The fabrication and inspection of Type E thermocouples is 1dent1cal with that of the Type C thermocouples except that, with the new insulation, the heattreatment is no longer required.

"TRIAXIAL" CABLE

Knowledge of the neutron flux at various points w1thin the reactor is desirable to the operator. Such measurements could be made with a spec1ally prepared device designed at the E. R. L. and described in DP-26. However, no cables were 
avallable to carry the signal through the high-flux fleld to a Junction box outside of the reactor.

Requests for design of these cables stated that they should consist of an Insulated wire covered by a tube which In turn was insulated and covered by a second tube. Tube and wire were to be 25 aluminum. The inner tube was to act as an electrical guard or shleld between the wire and the outer tube. The insulatfon was required to have a resistance of not less than $4 \times 10^{8}$ ohms for a maximum length of $35 \mathrm{ft}$. The cable was to operate in a liquid medium. The insulation could not break down on exposure to h1gh neutron flux.

The names "triax" and "triaxial" cable most commonly used when referring to this assembly are misnomers; there was actually only one axis, not three, as can be seen from F1gure 9 .

During the development, all tube drawing was done by the Prec1sion Tube Co., Philadelphia, Pa. The 1nner tube was drawn on a standard tube-drawing bull block. The outer tube, being less flexible, was drawn on a standard tube-drawing bench.

The usefulness of the "trlax" depended upon the overall dlameter of the cable. If the cable could be held to a max1mum diameter of $0.300 \mathrm{in.,} \mathrm{It} \mathrm{would} \mathrm{be} \mathrm{possible} \mathrm{to} \mathrm{insert}$ three cables within each instrument tube.

Insulation The minimum resistance of $4 \times 10^{8}$ ohms was a dif:1cult requirement. Ordinar1ly, cablas having such resistance depend upon any of several organic materlals for their high electrical Insulation resistance. Such materials as extruded polythene or resin-1mpregnated flbrous matertals are typ1cal. These materials, however, were arbitrarily excluded from use here.

The Investigation resolved itself into a study of five types of Insulation all of which were eventually made usable.

"Refras11" and the "Refras11" Cable Insulat1on selected as a final cholce was "Refrasil" s111ca yarn, a product of the H. I. Thompson Co., Los Angeles, Callf. "Refras11" is a boros111cate "F1berglas" yarn wh1ch has been leached w1th hydrochlor1c ac1d. Th1s produces a nearly pure silica yarn. An analysis is given in Table I.

Efforts to wrap or bra1d "Refras11" on a w1re as an Insulator for the Type $C$ and Type D thermocouples Ind1cated such a method to be impractical. It was decided 
to have Thompson bra1d the "Fiberglas" yarn Into a sleeve so that the inner w1re could be threaded w1thin this sleeve. It was thus possible to prepare "Refras11" sleeves by leaching and firing the "Fiberglas" already in the form of a sleeve. An aluminum tube could be drawn over the sleeving and $1 t$, in turn, could be threaded in a second sleeve. A final aluminum tube could be drawn over the assembly to form the completed cable. Ab1l1ty to thread the wire and the first tube in the "Refras11" sleeve resulted from the fact that the sleeve was bralded to behave like the we1l-known Chinese finger trap. As the ends of the sleeve were forced toward one another, the dlameter of the sleeve would grow. The w1re was then passed through the sleeve. The sleeve was then stretched out and the dlameter decreased so that the insulation fitted snugly about the wire. A similar procedure was used to thread the assembly 1nto the outer alum1num tube. Figure 8 shows a dlagram of this catle and a pleture of a $16-1 \mathrm{n}$. lergth.

The as-recelved "Refras11" sleeve had an electrical resistance of the order of 106 to $107 \mathrm{ohms} / 35 \mathrm{ft}$. of cable. It was establ1shed that heat-treat1ng the "Refras11" at $1800^{\circ} \mathrm{F}$ for $8 \mathrm{hr}$. would provide an insulated cable with a resistance between any two elements of 1011 ohms. Heattreatment at lower temperatures did not show this improvement. However, the treated material was so embrittled that handling would have been impossible. A compromise heat-treatment of $2 \mathrm{hr}$. at $18000 \mathrm{~F}$. was found to give cable resistances of $109-1010$ ohms without excessive embrittlement if handled in the braided-sleeve form.

Arrangements were made $w 1$ th the Thompson Co. to suply the appropriate sizes of "Refrasil" sleeving as established by trial. They were to take special pains to assure maximum silica and minimum boron contents by careful and thorough leaching and washing. They would cert1fy a maximum boron content of 200 p.p.m., wh1ch was acceptable to the du Pont operating department.

By agreement, the code numbers S-100-1-DS and S-1002-ADS were chosen to refer to the sleeving whlch would be used specifically for the Inner and outer insulation, respectively, of these cables.

1. Fabrication Procedure The fabrication steps are as Pollows: 
a. An approprlate length of $0.032-1 n$. diam. 2S aluminum wire is threaded through the same length of S-100-1-DS "Refras11" sleeve. The sleeving is then stretched out lengthw1se so that it fits snugly about the wire.

b. Th1s insulated wire is arawn through a $2 S$ alumInum tube with a $0.010-1 n$. wall and an apprortmate dlameter of $0.180-1$.

c. The tube is drawn down to a $0.120-1 \mathrm{n}$. o. d. on a standard tube-drawing bull block. The 1 . d. of the tube now meets the $o$. d. of the sleeving.

d. This assembly is straightened and cleaned of drawing lubricants.

e. It 1s threaded through a length of $S-100-2$ ADS "Refras1l" sleeving. This sleeving is then drawn out unt1l it fits snugly about the aluminum tube.

f. This is threaded through an aluminum tube with a $0.049-1 n$. wall and an 0 . d. of $0.400 \mathrm{in}$.

g. The outer tube 1 s drawn down to an 0 . d. of 0.298 1n. The 1. d. of the tube now just meets the o. d. of the larger "Refrasil" sleeve. Welding of the measuring device to the outer tube wall 18 possible because of the $0.049-i n$. wall thickness.

h. All metal members must be carefully cleaned before assembly so that no organic drawing lubricants are included.

Asbestos and the Asbestos Cable The cable Insulated with asbestos had the same dimensions as the cable insulated w1th "Refras11" s1l1ca f1ber, and the Inner tube of the latter cable was replaced by bralded $2 S$ aluminum w1re.

As-recelved asbestos is a poor insulator just as 1s as-recelved "Refras11". Conmerclal asbestos Insulation is always Impregnated with a varnish or similar organic binder if high electrical resistance is required.

Attempts to heat-treat this fiber in order to improve the resistance at first indicated that, although the resistance could be brought to a sat1sfactory level, the physical properties deterlorated markedly and carding it on 
wive and tubing would be impossible. The 1deal heattreating condittons were $1 \mathrm{hr}$, at over $1,0000 \mathrm{~F}$.

Severval cables were prepared with the tubing 1dent1cal in size with that on the "Refras11" cable shown in Figure 8. The cables were then heat-treated after fabrication. The $1025 \% \mathrm{~F}$. temperature used was near the $1180^{\circ} \mathrm{F}$. melting point of the $2 S$ aluminum. During heat-treatment, the evolved water of crystallization ruptured the soft aluminum tube walls.

Two solutions to this difflculty were found. First, 1t was learned that, if asbestos was heat-treated in small batches for not more than $1 \mathrm{hr}$. at 1,000\%F., the min1mum acceptable resistance was achleved. Although the phys1cal propertles were poor owing to embrittlement, it was st11i possible--though difficult--to card the fibers on to a wire. Second; a cable was designed in which the inner tube was replaced w1th a bra1ded $2 S$ aluminum wire sleeve. A second cover of asbestos was applled over the aluminum braid and the entire assembly heat-treated after Insulation but before covering with the outer tube. The open aluminum braid could pass the water vapor evolved during heat-treatment.

The resistagce of such cables varled somewhat but averaged $5-8 \times 10^{8}$ ohms for a 35-rt. length. From a fabrication point of view, the second type of asbestos cable ilsted above was preferred over the first, but ne1ther was as simple to make nor as high and uniform in electrical resistance as the cable Insulated with "Refras11".

Ceramics and the Ceramic Cables The use of ceramic tubes as Insulators was considered, but it was quickly learned that the goal of a $0.300-1$. 0 . d. maximum could not be reached. However, cables w1th an 0 . d. of $0.500 \mathrm{in}$. were designed and the components ordered. These cables would have been used had the efforts to provide a high-resistance "Refras 11 " or asbestos-insulated cable falled. The large o. d. of these cables would have 11 mited the number of devices to one per 1nstrument tube. The 1 imiting factor was the Inablilty of the suppliers to provide small-diameter thin-wall ceramic tubes.

Figure 9 shows the proposed design of the ceramicinsulated "Tr1ax". Fabrication would have been done by hand. The wide spacing between the Insulators and the. aluminum elements was required to provide for (a) maximum warpage of $0.006 \mathrm{in}$./ In. along the length of the insulators, 
(b) the $-0.010-1 n$. 0. d. and 1. d. tolerances required by Insulator suppliers, and (c) free slippage of the 1nsulators along the wire and tubes during assembly.

Three types of 1nsulators were ohosen. "AlS1Mag" Ceramic is an $\mathrm{Al}_{2} \mathrm{O}_{3}-\mathrm{MgO}-\mathrm{S}_{1} \mathrm{O}_{2}$ body made by the American Lava Co.; "Alundum" fused alumina $1 \mathrm{~s}$ a product of the Norton Co.; and "Amers11" fused s111ca is made by the American Silica Co. Any of these would haye provided a cable with a resistance of the order of 1014 ohms.

Development was d1scont1nued when smal1-d1ameter cables having sufficlently high resistance were fabricated using e1ther "Refrasil" or asbestos.

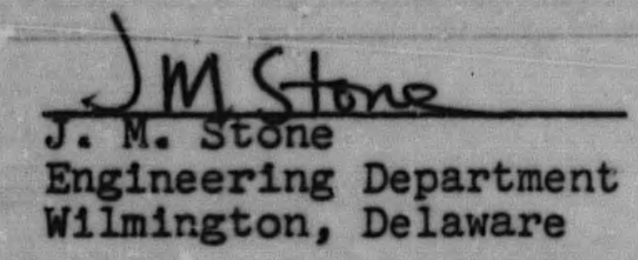




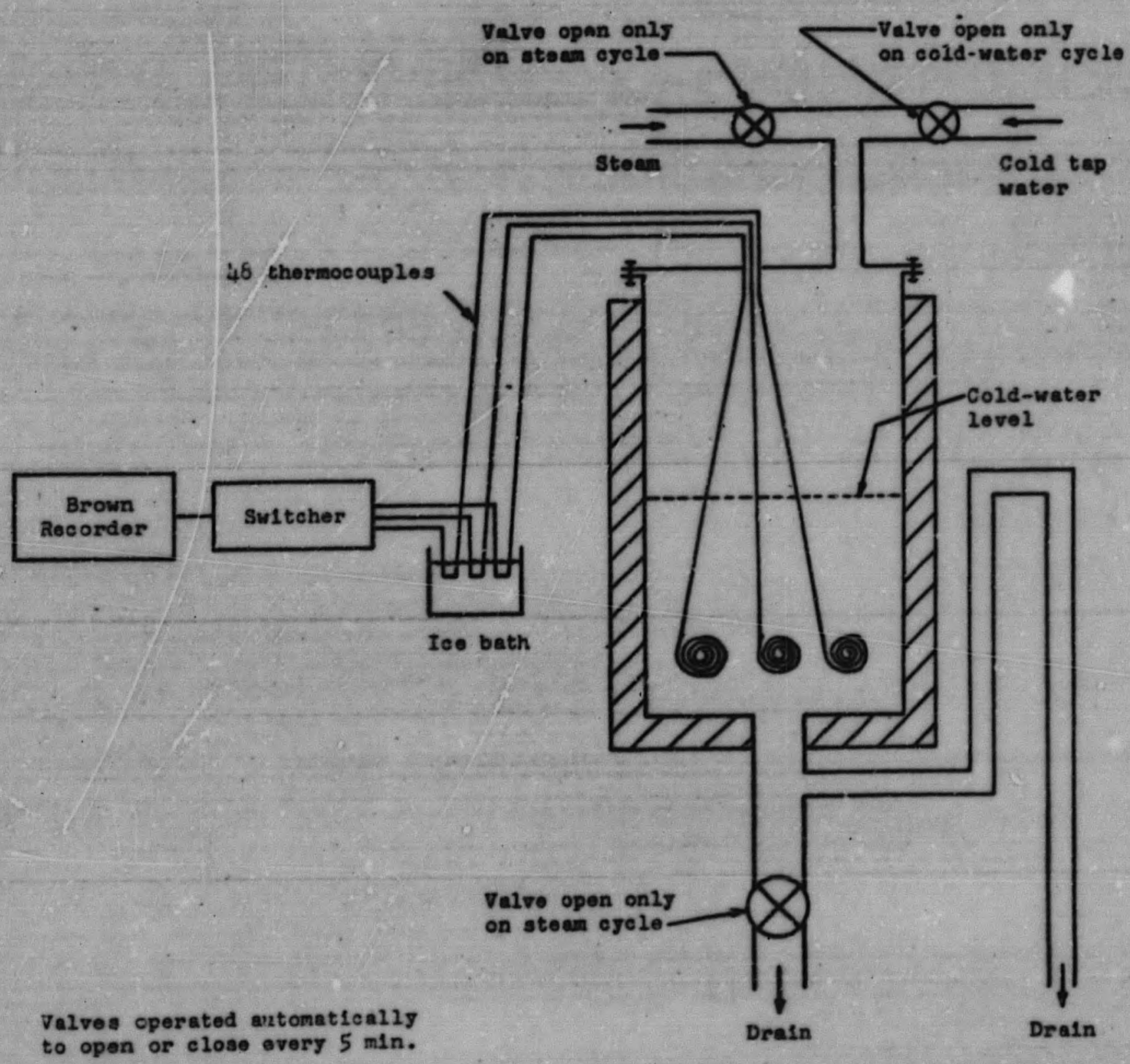




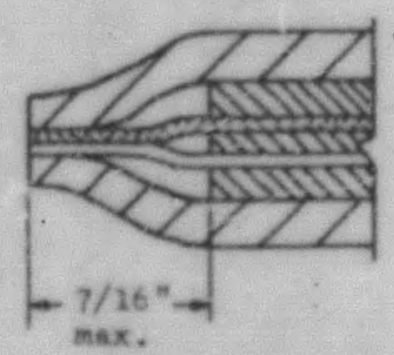

Thermocouple Junetion prior To weiding

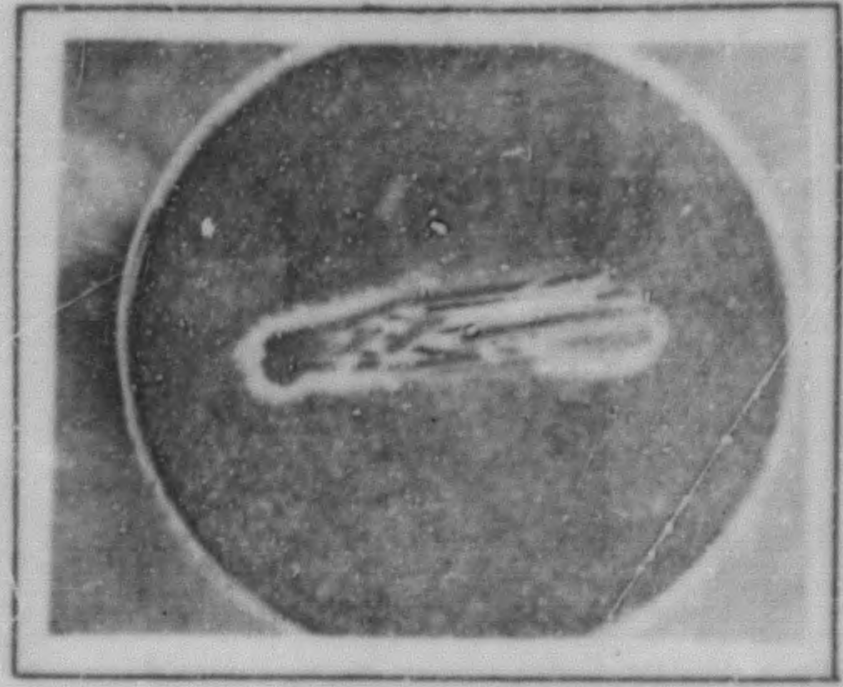

Typtenl weld Seotion:

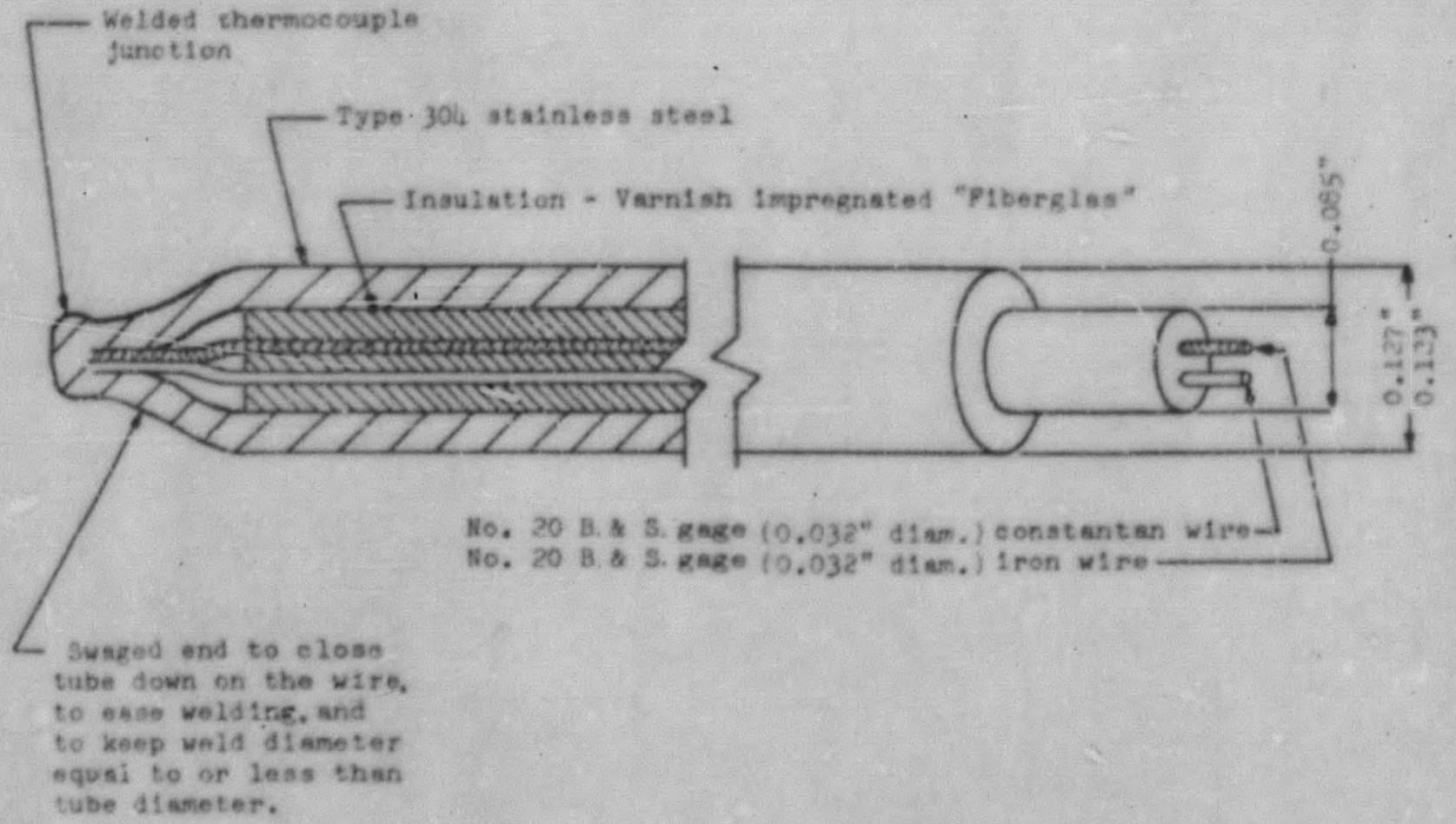

TXYE A THERMOCOUPLE 


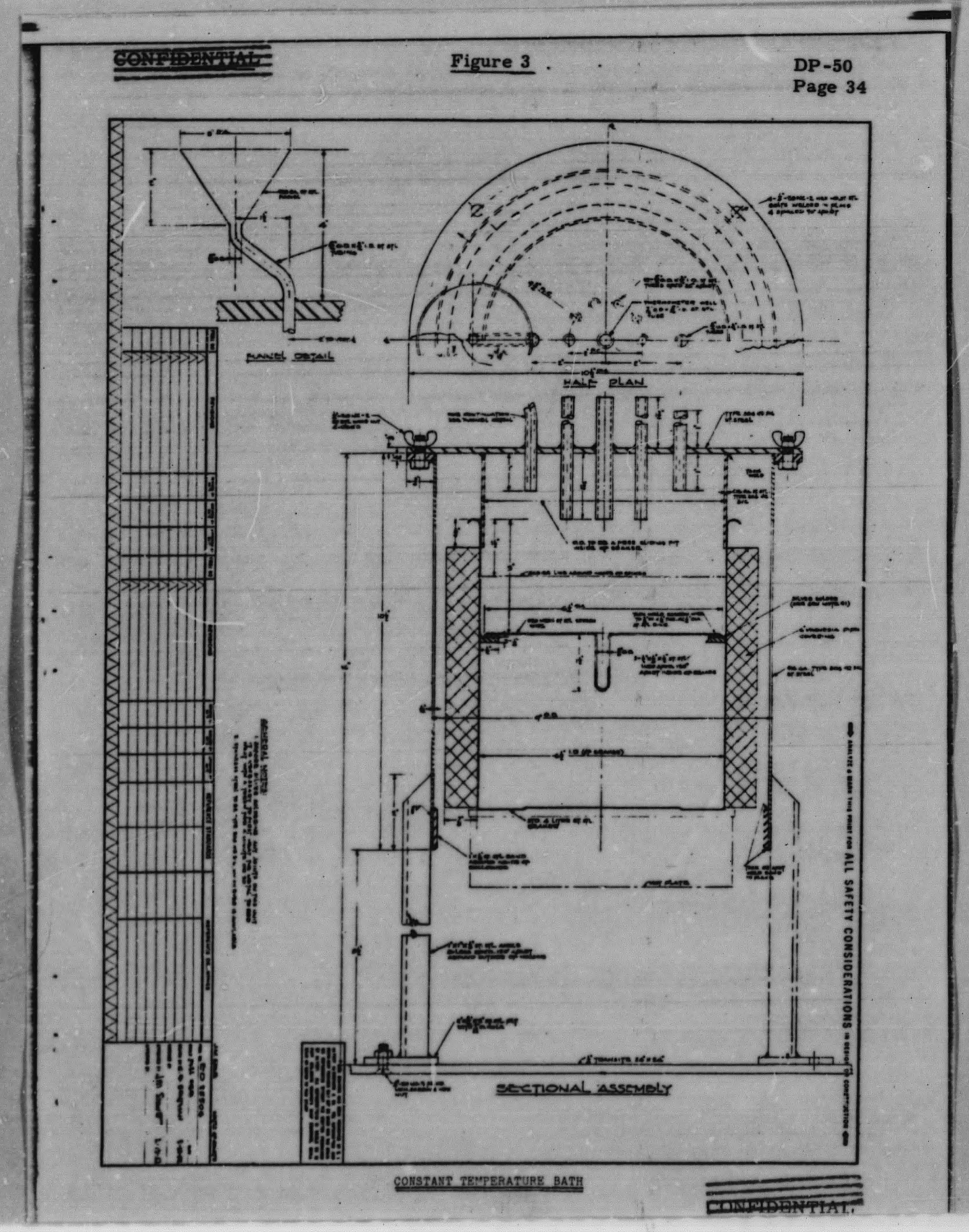




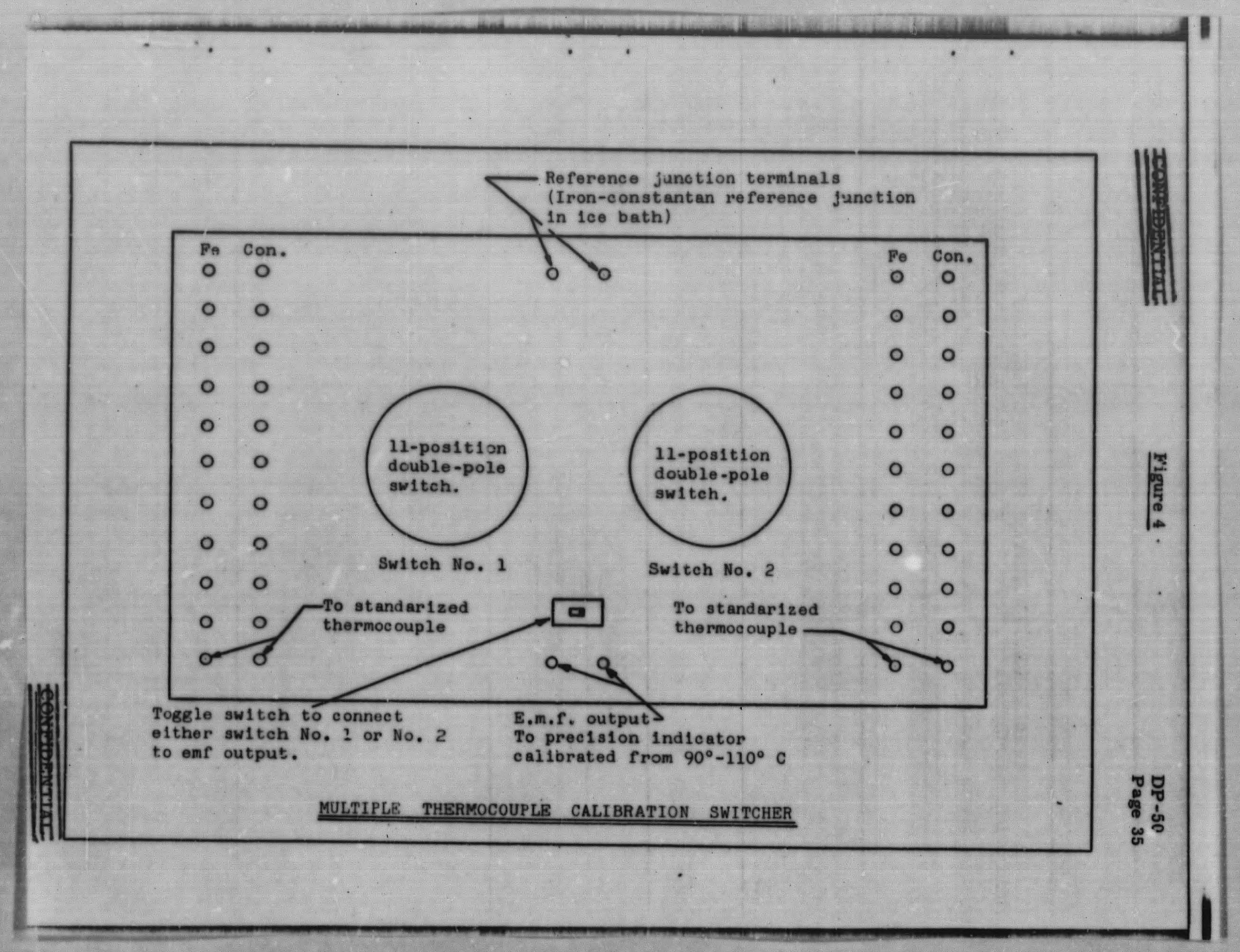




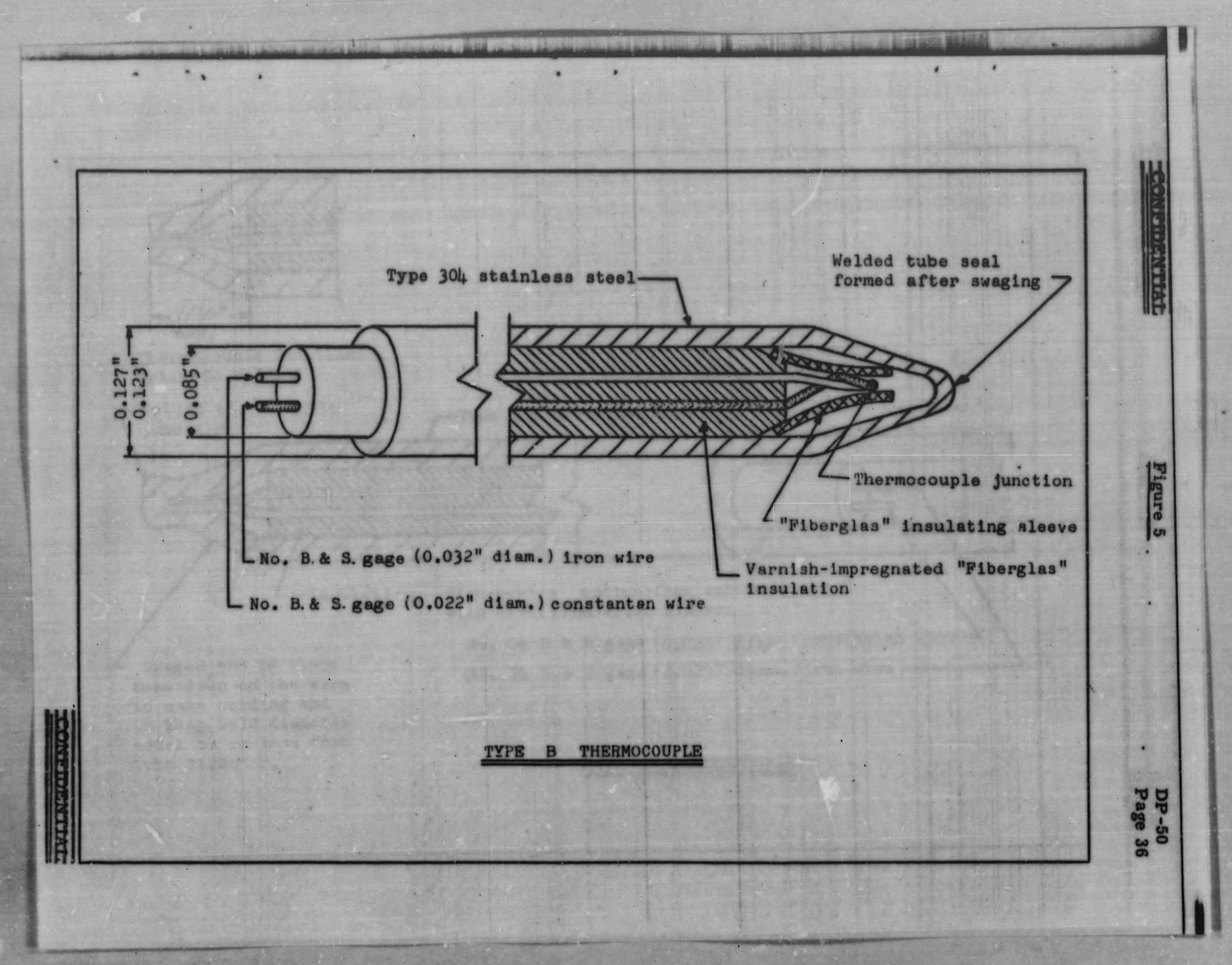




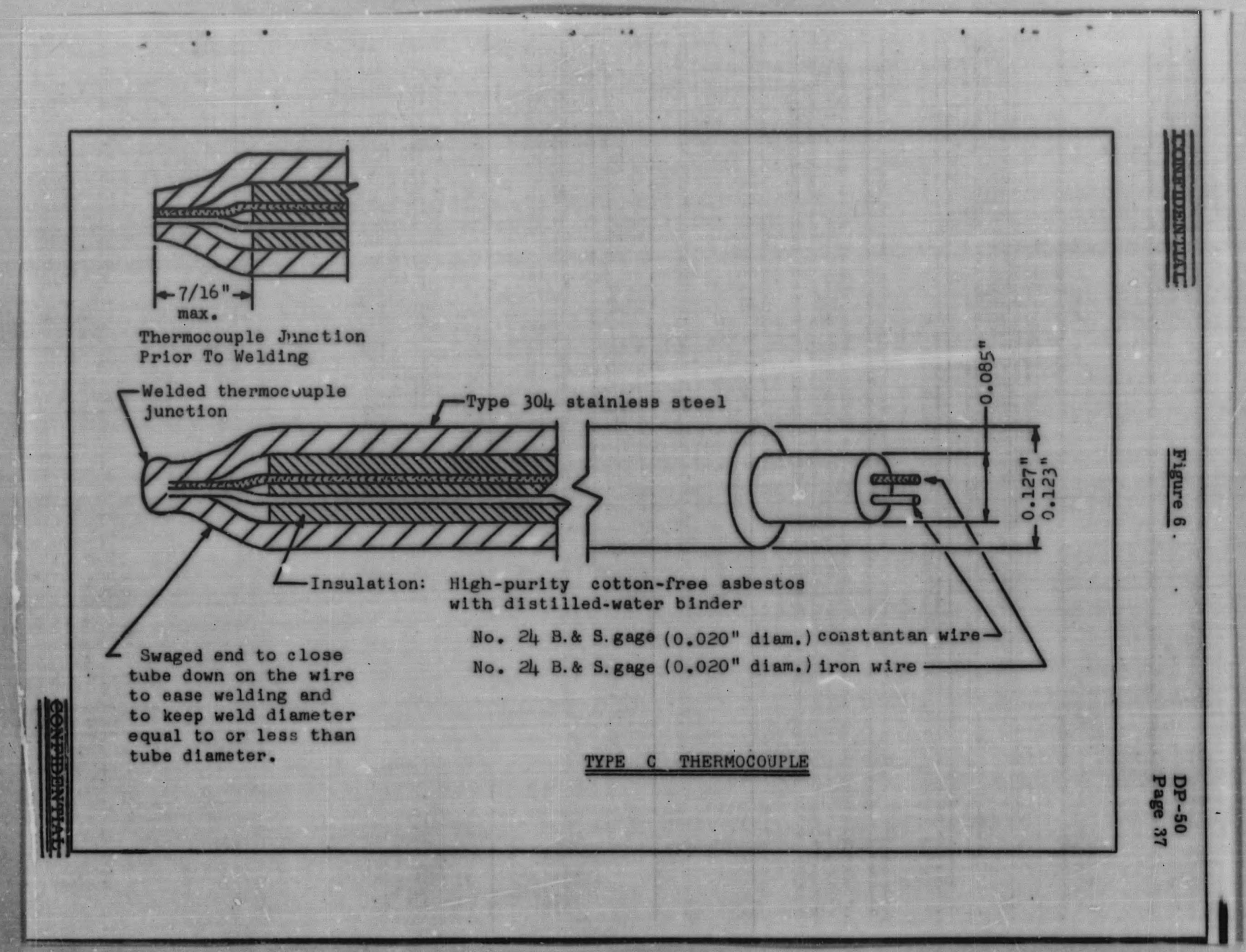




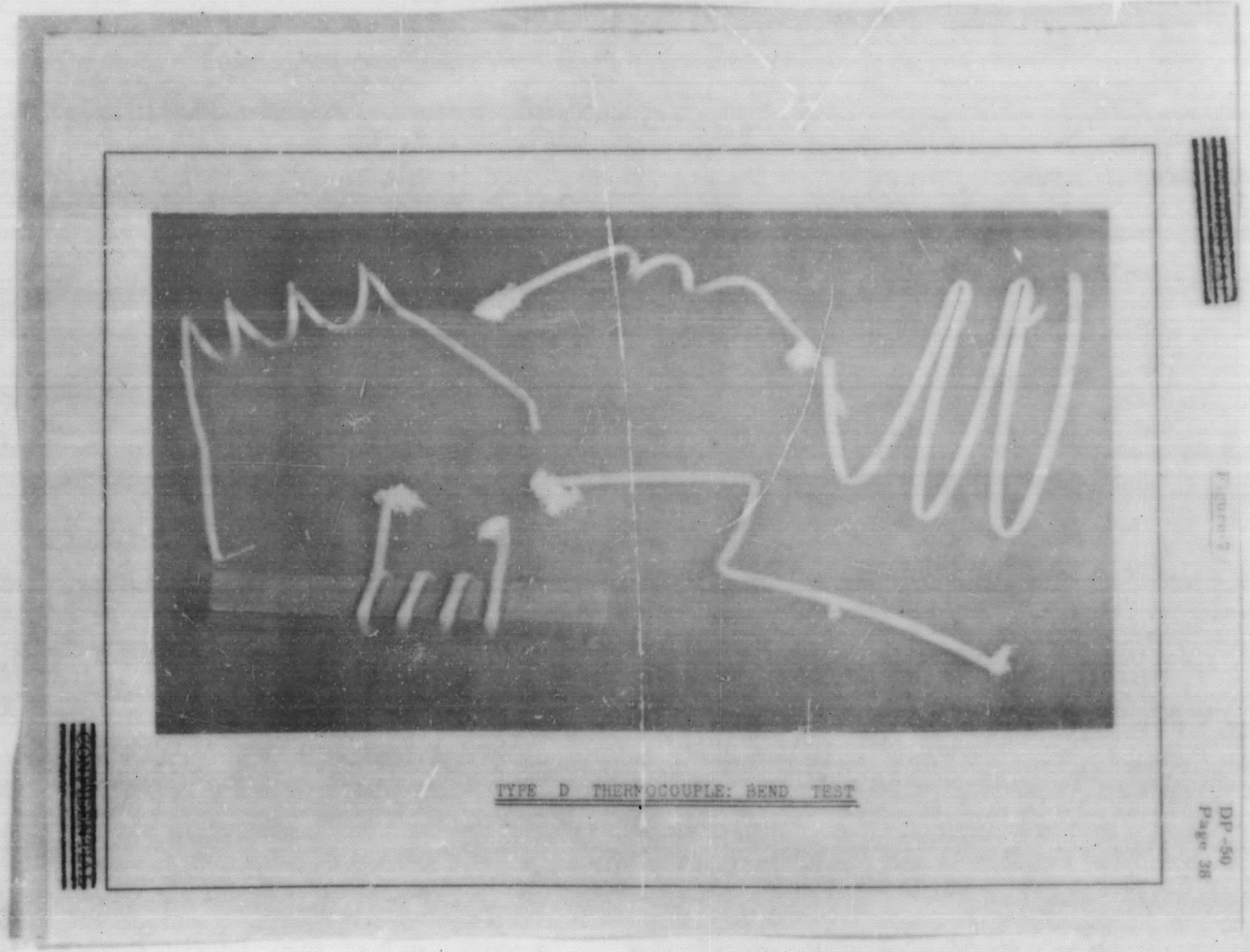




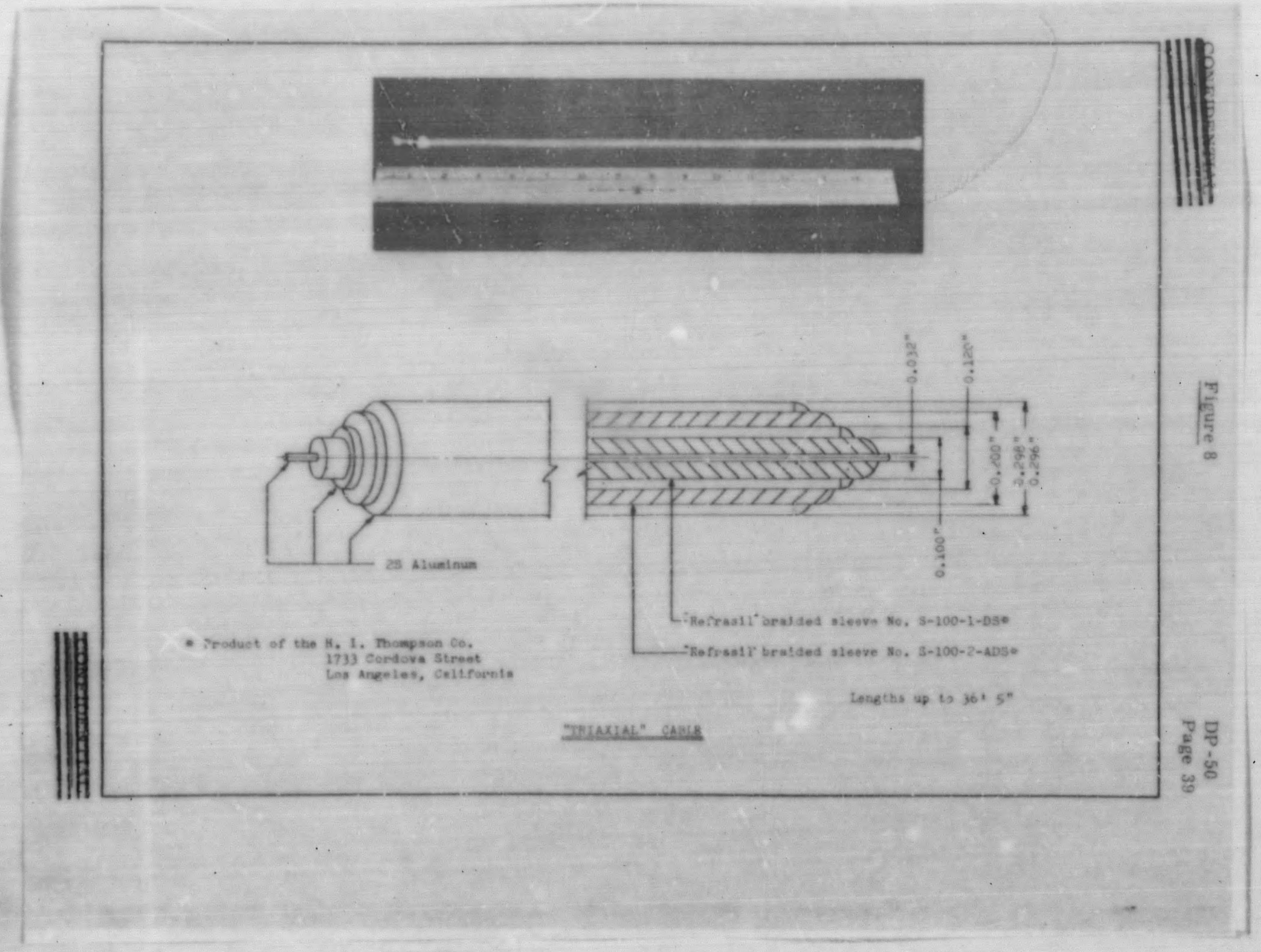




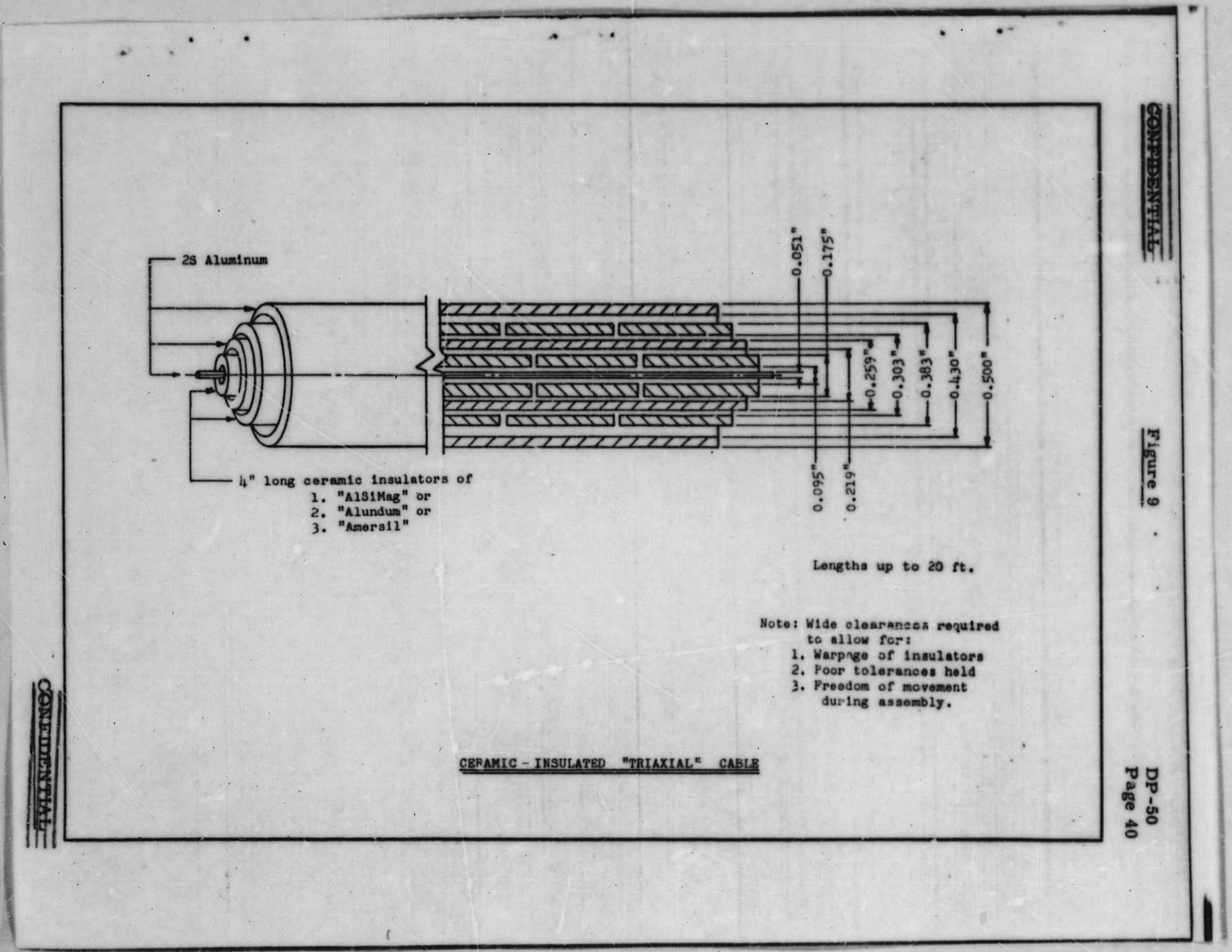



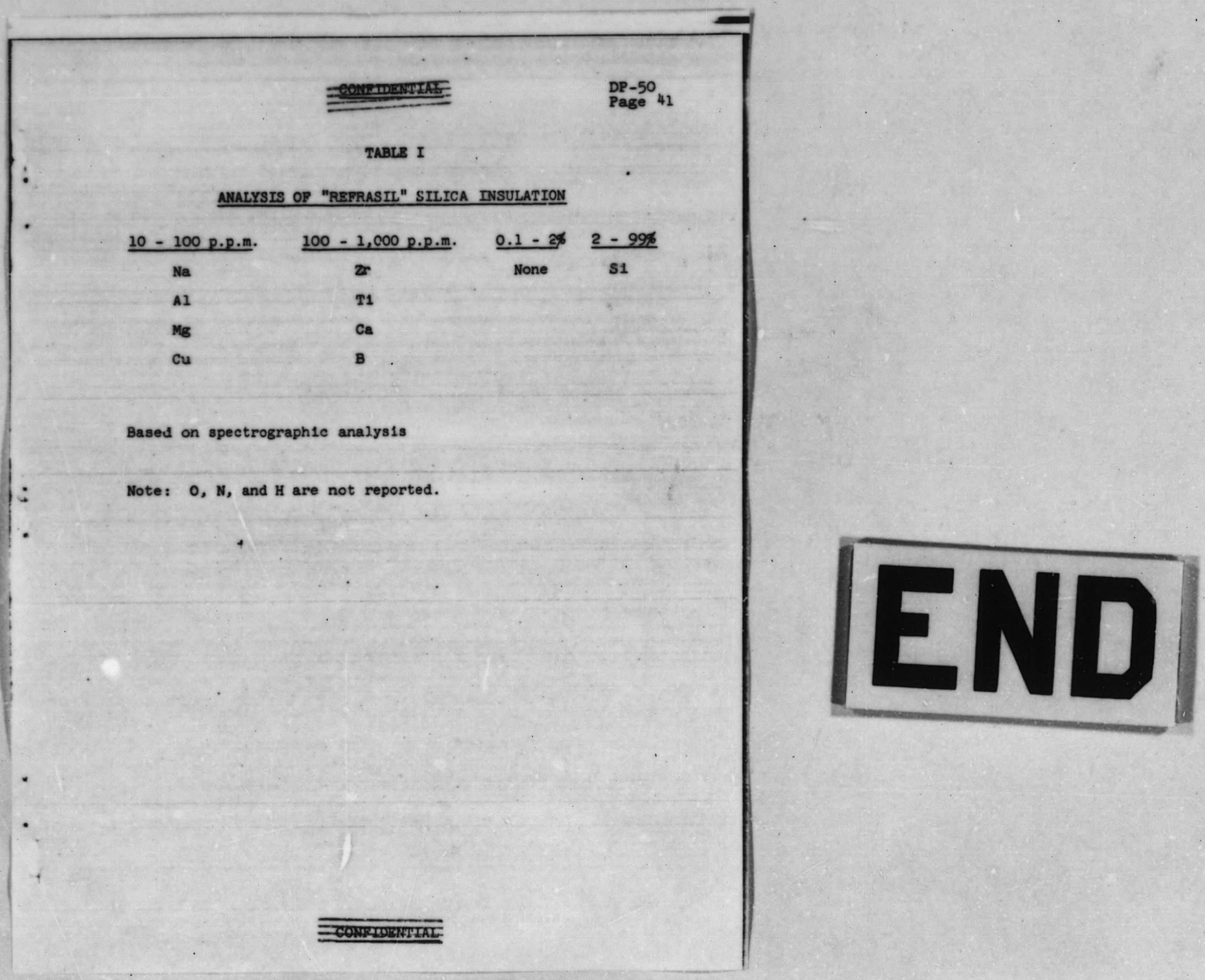